\title{
How to Cultivate Intercultural Communication Competence of Non-English Major Students
}

\author{
Wei Sun \\ School of Foreign Languages, Qingdao University of Science and Technology, Qingdao, China
}

\begin{abstract}
In fact students have already received almost totally grammatical rules during their several years study, but they often lack of the ability to actually use English and to understand the use in normal intercultural communication. Misunderstandings caused by cultural differences have involved them frequently in intercultural miscommunication. The purpose of this paper is to present the concept of intercultural communication competence, focus its importance on foreign language teaching, and indicate how to cultivate students' intercultural communication competence. The writer emphasis the relationship between culture and language, communication and culture, she briefly introduces the situation in foreign language teaching in the past and today. In this paper, the author try to illustrate how to cultivate students who are not English major to understand the cultural meanings of language, and try to help them use English properly, especially in special context.
\end{abstract}

Index Terms - foreign language teaching, teaching in context, intercultural communication training

\section{INTRODUCTION}

In modern society, because of globalization, communications between nations is widely active. On another hand, economic area has shifted from developed country to developing country. Therefore, the communication between people who are from different cultural background is more and more prevalent. During the connection, people who have intercultural communication competence are easy to achieve their goal in their notational, particularly in business world. From this point of view, as a college teacher, we have to think about how to make our students have ability to receive the challenge after their graduation, how to make them communicate properly with foreigners, and how to train or cultivate their competence of interculture communication.

Globalization is an unavoidable process of development of society, it is also an important trait of modernization, and it is a major trend of the world. To be specific, globalization is a connection which makes economy as the core, including politic, culture, technology, military, security, style of life, value and so on. In fact, globalization is a concept of diversification.

Economic globalization has brought the profound influence on the world economy and great changes. Economic development and international economic situation of a country or a region is becoming more and more closely. Intercultural communication is increasingly frequent used In the field of economic and technological cooperation with countries around the world. At the same time, due to the cultural differences between various misunderstandings and conflicts also followed. in such a new situation, face the great challenge of globalization and strong effect, we not only need more skillful English users but also need people who can accurately grasp the cultural differences between China and foreign countries in foreign exchange, they must has a good ability to intercultural communication, in order to more properly conducting external exchanges, adapt to the growing international economic exchanges and the needs of the growing national strength competition.

\section{LiterATURE REVIEW}

i. Connections between language and culture

At the very beginner, we should clarify what language is, what function it has, and what relationship between language and culture is. First, Language is a tool for communication, people use it to inform, chat, request, express, persuade exchange and to try to make their expressions be understood by others. Language plays a crucial role in the process of human historical development.

Language is a part of the culture. it is a special kind of social phenomenon human created by human being, is the most important tool of human communication, language as tool of human minds are not isolated, but with many physical phenomenon. it can provide service for human beings, human cannot leave it all the time; Although it's not a pure spiritual phenomenon, it also can well reflect the spirit of the characteristics of the human material world through language, the state of human spirit can be carefully to interpret and so language is, of course, become a part of the culture.

As a kind of social phenomenon, language is not only as a tool for human communication, at the same time; language also has the function of recording culture. People record the understanding of the human life and natural phenomena by using language. 
Language and culture are closely related with each other. As everyone knows, language has been playing an important role in the process of human historical development. We as human beings are unique in the world due to we have language, we can communicate each other freely---to make sounds and marks serve as substitutes for things and feelings.

In the past, people usually regarded language as simply marks, which has no influence in human development. It was just a tool by which ideas were indicated, rather than an effective method of expression of culture. This view had been canceled by later linguists. The new point is that language and culture are closely linked with each other. Language is the reflection of culture and culture is a reflection of language.

Culture influences language by our perceptions of the universe, and the world we live in. Every time we choose words, make sentences, and express our feelings, in oral or written, we also make cultural choices. If we select language without being aware of the cultural implications, we may not communicate well if we choose words randomly without considering its cultural meaning. Language, therefore, is perceived as window to the culture. In a word, it is impossible to separate language and culture apart.

However, In our traditional class, the aim of teaching is not a high quality education, whose norm is greatly affected by structuralism taught in a pure and abstract form, focused on grammatical rules or semantic meanings of certain words or phrases. Teachers seldom tell their students cultural meaning of certain expressions and background knowledge. This kind of teaching leads to some difficulties in understanding cultural knowledge and produce serious consequence learners incompetence in intercultural communication in the use of this language. So, nowadays, more and more teachers pour almost all their energy and time to the study of intercultural communication, and try to reform the teaching strategies so as to develop effective intercultural communication competence for learners. In this paper, the author tries to emphasize the importance of intercultural competence and aims at analyze how to cultivate the intercultural competence of Chinese English learners.

The link between culture and communication is so important that it goes through the influence of culture that people learn to communicate. Once people from different culture meet face in face, cultural difference must be considered. Their communication practice differs from that of people in the same culture. Hence, in language learning, culture competence is as crucial as linguistic competence. As foreign language teachers, we have responsibility to make our students know exactly how to use language appropriately.

\section{ii. Definitions of culture}

To define intercultural communication competence, we must first define culture.

A working definition of culture is; the sum total of ways of living built up by a group of human beings, which is transmitted from one generation to another. (The modern Chinese dictionary, 1998)

Culture is the arts and other manifestations of human intellectual achievement regarded collectively, the customs, civilizations and achievement of a particular time or people, improvement by mental or physical training. (The concise oxford dictionary, 2001)

This means personality, how people express themselves (including shows of emotion), the way they think, how they move, how problems are solved, how their cities are planned and laid out, how transportation systems function and are organized, as well as how economic and government systems are put together and function." (Edward T. Hall, 40)

\section{iii. Definitions of Intercultural Communication Competence}

Intercultural communication is a kind of communicative behavior, communication type, can be the interpersonal communication, can also is a person with the public (community) communication. Brian Spitzberg (1973) thought that communication ability of the individual embodies in the individual appropriate effective communicative behavior in specific situations in the context of intercultural communication; both parties have in common, differences, more communication, cultural differences affect the effective communication of variables such as language differences worldview values. Kramsch (1993) for a more specific definition of intercultural communication skills: ability to cross-cultural communication is individual has the intrinsic ability, able to handle the key problems in cross-cultural communication, such as cultural differences strangeness, this cultural attitude within groups, and the resulting psychological pressure, etc. Since Hymes (1971) put forward the concept of communicative competence, the scholars at home and abroad has not end their study for communication skills, especially on the discussion of intercultural communicative competence. Although scholars has different definition and classification in view of the communicative competence or ability to intercultural communication mode, but communicative competence should at least include grammatical correctness of speech act and social appropriateness of verbal behavior. Some foreign scholars believe that intercultural communicative competence includes cognitive emotional behavior aspects of adaptability; the ability of the communicator can according to the actual situation in the intercultural communication, to learn and adapt to the different cultural habits, and can deal with the cultural differences between the two communicating parties creatively. people who has the ability of intercultural communication, not only to master the two or more cultural knowledge, more important is to experience the process of cultural harmony, thus thoroughly at home in the process of communication, communication smoothly achieve the desired goal. in this sense, to improve students' intercultural communication ability as the goal of college English teaching, can better meet society's need for high-quality talents.

\section{RESUlTS AND ANALYSIS}




\section{i. Factors that cause intercultural communication obstacles \\ Different mode of thinking and value ideas}

Because of cultural differences it is frequently caused communication barriers In intercultural communication. He culture will influence people to the outside world views and understanding, different countries have different culture, so there must be differences in thought patterns. This is obvious between Chinese and western culture. The thinking mode of westerners is more logical, rational analytic, and the thinking mode of Chinese is rely more on intuition, it seems like more general and ambiguity.

Cultural differences also present in the differences of values. Every culture has its unique value system. Values attitude determines people's beliefs and actions from different cultural backgrounds, if each starting from their own values, cultural differences, for which affect intercultural communication.

In the process of socialization, People learned the value system of their own culture unconsciously. The value they acquired becomes their philosophy moral standard and code of conduct. However, every culture has a unique value system, criterion. in one culture it is considered to be normal, in another culture may be considered to be of eccentric. characteristics of western culture is a value above; And the characteristics of the Oriental culture is emphasis collective values. in Chinese culture, people praise highly humble comity, promoting mutual support and on collective responsibility, the pursuit of settling; In individual orientation of the western culture, it could be described as a lack of enterprising spirit, people advocate personal struggle for independence pursuit ego. They praise great importance to personal freedom development, request personal space and power to protect personal privacy.

\section{Emotional factors}

The emotional factors in cross-cultural communication refer to the communicator with communicative objects from different cultures and intercultural communication behavior attitude. One important feature is the anxiety to the intercultural communication activities.

People who have High degree of intercultural communication anxiety tend to avoid communication with people from the foreign culture, whether one is willing to communicate is an important emotional factor in intercultural communication. The more knowledge of Intercultural communication one has the smaller psychological pressure one may has, the stronger the motivation for intercultural communication. The more opportunity to gain experience in intercultural communication, one may has.

\section{Discussion}

\section{i.The importance of cultivating intercultural communication competence}

\section{Cultivation of intercultural awareness}

Whether one has intercultural awareness or not directly affect the quality of communication, it also can measure whether he is a successful communicator and whether he achieves intercultural communication purpose. If we want to make our students be successful communicators, we must start from the cultivation of intercultural awareness in particular, in college English teaching is to develop two kinds of culture consciousness: one is the consciousness of cultural equality, the other is the consciousness of cultural understanding.

Firstly, the consciousness of cultural equality communication is based on respect for different cultural tolerance and understanding of native cultural identity. As teachers, we should teach students to treat every vision culture, gently and objectively, derive the essence, discard the dregs. On the other hand, we should strengthen the education of traditional culture of the Chinese nation. Secondly, developing students' consciousness of cultural understanding refers to jump out of one's own cultural values, to view and evaluate each other on each other's cultural values, learn tolerate respect and understand others with their own different, only in this way, we can achieve the intercultural communication smoothly.

\section{Teaching in intercultural dimension}

The main purpose of intercultural ability training is to train students to become able to adapt to the complexity of the different culture and also make them become multiple identities in modern society. Intercultural communication should be based on respect for individual and the equality of human rights. Intercultural ability is to ensure that one can be understood by people from different social status. People who have intercultural ability in communicate can make oneself maintaining multiple identity and individuality while he communicates with others.

The best language teacher is neither the native speaker, nor is the non-native speaker, but for one who can help students to see the relationship between different culture and himself. he can make them interested in other cultures and make them full of curiosity, meanwhile, he also help the students know exactly what their own culture like in foreigners eyes.

In language teaching, teachers should cultivate the students' ability of language, at the same time also cultivate intercultural ability; make them have the ability to communicate with people from other cultures; make the students understand and accept different cultural, let them know the different views of value and behaviors; To help students clear that it is a process of experience gaining of communication with people from other countries. The teacher does not need to have experience of living in other different cultures or be expert in certain field. The teacher's task is to help students to ask questions and try to give them answers.

To visit and practice class of the target language communication is not just a chance; it also is a kind of overall learning experience. If teachers can create this kind of communication mode, Students will obtain knowledge and 
experience from visiting. This knowledge can hardly receive from communication in the classroom. During lecture, teachers should make students aware the implicit values and significance of the learned material, thus, using real material is very important.

\section{Strengthen the practice ability of intercultural communication}

Whether a person really has the ability of intercultural communication, not just see if he grasps the cultural knowledge and communication skills, more important is to see whether he can flexibly deal with the actual problems in intercultural communication. So it is not enough only attaches importance to students how to study cross-cultural communication in the classroom. In the process of the cultivation of intercultural communicative competence, teachers must be arranged in a planned way and encourage students to actively participate in the practice of intercultural communication. Students should be encouraged to associate with people from different cultural backgrounds, to deepen the understanding of cultural differences, cultivate the flexibility of dealing with cultural differences, enhance the sensitivity of culture, learning and using of intercultural communication skills, let them improve their intercultural communication ability in directly.

\section{ii. Methods of intercultural communication competence training}

\section{Changing of teaching concept}

In our country, foreign language teaching is mostly only in the classroom, teachers play an absolute role. only if teachers focus on grammar and vocabulary teaching, the students could not grasp the language ability of practical application, and also do not have access to intercultural communication ability, therefore, the teacher must change their concepts, to realize the actual existence of cultural conflict and the importance of cultivating students' intercultural communication consciousness and ability. at the same time, English teachers should improve their comprehensive cultural quality; comprehensive grasp of English; and the concrete methods; steps of teaching. Only in this way, teachers can achieve the expected teaching purpose. In another aspects, teachers may strengthen the contrast and comparison of Chinese and western cultural differences, the Chinese and western cultural differences in various aspects of consciousness naturally penetrate into teaching progress.

\section{Changing of teaching method}

Of college English teaching emphasis on language knowledge teaching, and neglected the cultivation of the intercultural communication consciousness and ability. in order to change this situation, we must improve the method of teaching, teachers should control teaching process in quality and quantity two aspects and make full use of modern teaching means to mobilize students' learning enthusiasm. In improving teaching methods, be sure to make the new contents closely linked to the knowledge of materials, and closely integrated with language communication practice. Make full use of the diversity of classroom teaching and flexibility to cultivate students' intercultural consciousness and ability, strengthen the introduction of cultural background knowledge, lets the student understand the multiple perspectives to its culture in learning a language. Teachers also should Guide students to read more, to contact with western culture, and to help students learning to use, through the combination of theory and application, to deepen the understanding of culture, thus improve the intercultural communicative competence.

\section{iii. Introduction of background knowledge of different culture in class}

Teachers can introduce some background knowledge of other countries which is concerned in teaching material. Differences between Chinese and western civilization is widely used in verbal communication, but Chinese students lack of natural language acquisition environment, therefore, Teachers should make great efforts to activate the teaching material content, promptly tell students to figure out the difference between different cultures.

\section{iv. Cultivation of non-verbal communication ability}

Nonverbal communication is also an important way of communication. It refers to the process of information communication by using nonverbal behaviors in a specific context of situation. They are not real language units, but sometimes they can express more strongly than words in life and communication. the meaning of some certain non-verbal behavior often represents a certain meaning, must be pay attention to in intercultural communication. under certain background, the difference of nonverbal communication between Chinese and western culture is very wide, for example, the Chinese believe in silence is golden, think silence contains rich information, and English speaking countries people have very uncomfortable feelings when Chinese keep silence in conversation; Westerners conversation, the listener is generally long time looking at each other's eyes, to show the listener's serious and respect for the speaker, but in the Chinese point of view, this is a kind of rude behavior, because the Chinese are not used to stare at each other for a long time.

\section{v. Using physical objects and pictures}

Because the students generally have no personal feelings towards social cultural knowledge in foreign countries, if teachers only rely on reading written material or explain abstract concept is difficult to achieve the teaching purpose, therefore, to make students feel the foreign culture, to understand its real meaning, in the teaching should be as vivid teaching method, in which physical pictures and photographs is relatively easy to be understood. For example, when teachers in the interpretation of the sign language, available pictures vividly expressed OK Good luck, welcome such western gestures, this is much more clear than only illustrate by words, and in the process to produce novelty and affection, and help to cultivate students curious of foreign culture, and also provides a prerequisite for learning skills.

\section{vi. Role playing}


Role playing is a English teaching activity. in this activity, students play with characters, and the things that happen in a certain situation in foreign language and certain actions. It greatly promotes the development of communicative competence, such as listening to the application, ability of language, sense, observation, flexibility, imagination and improvisation.

Teachers can also suggest advanced level students to see some British and Americana movies. Not only because most of the content of the film itself is a microcosm of the one side of a culture, but also is the view in the actor's performance can make the students understand and learn many methods and means of nonverbal communication. It is very important for our students to communicate with native speakers from foreign language learning point of view. So teachers should encourage students to chat with them, so that students can often learn many vivid expressions that they may not learn in classroom.

\section{CONCLUSION}

From the aspects of theory, the significance of the cultivation of intercultural communicative competence is obvious. It provides some useful ideas for English teaching. Apparently, it is important to note that although culture of human thinking mode and behavior patterns of the dominant factor, but race, personality, ethnicity, age, gender, economic status, religious and other aspects will affect its understanding. Culture is dynamic, the world has a tendency to from collision to the compatibility, and the frequent communication between different cultures is unavoidable. so that the content of the intercultural communicative competence should also be dynamic, it helps put forward the intercultural communication competence training effectively.

\section{REFERENCES}

[1] Byram, M. (2000). Assessing intercultural competence in language teaching. Sprogforum, 52-60.

[2] Carbaugh, D. (1990).Cultural Communication and Intercultural Contact. Hillsdale, NJ: Erlbaum. Associates

[3] Canale, M. \& Swain, M. (1980) "Theoretical Bases of Communicative Approaches to Second Language Teaching and Testing." Applied Linguistics, 1: 1-47.

[4] Cook, v. (1999). Going beyond the native speaker in language teaching. TESOL Quarterly, 33/2: 185-209.

[5] Deborah. (1992). Language Socialization in the Second Language Classroom. Language Learning, 42(4): 593-616.

[6] Fasold, Ralph. (2000). The sociolinguistics of language. Foreign language teaching and research press. Oxford: Oxford University Press.

[7] Hymes, D. H. (1971). On Communicative Competence. Philadelphia: University of Pennsylvania Press.

[8] Kramsch, C. (1993). Context and Culture in Language Teaching. Oxford: Oxford University Press.

[9] Krashen, S. D. (1981). Second Language Acquisition and Second Language Learning. Oxford: Pergamon Press.

[10] Smaovar, L. \& Porter, R. (1972).Intercultural Communication: A Reader, Belmont, California: Wadsworth Publishing House.

[11] Samovar, L. A. (1998.) Communication between Cultures. California: Wadsworth Publishing Company.

[12] Schmidt, Richard W. (1983). Interaction, Acculturation, and the Acquisition of Communicative Competence: A Case Study of an Adult. Sociolinguistics and language acquisition. (137-174).

Wei Sun was born in Changchun, China in 1981. She received her master's degree in linguistics from Northeast Normal University, China in 2006. She is currently a lecturer in the School of Foreign Languages, Qingdao University of Science and Technology, Qingdao, Shandong province, China. Her research interests include psycholinguistics, teaching methodology intercultural communication, and second language learning. 